\title{
Ability, academic climate, and going abroad for work or pursuing a PhD
}

Citation for published version (APA):

Bertrand-Cloodt, D. A. M., Cörvers, F., \& Heijke, J. A. M. (2014). Ability, academic climate, and going abroad for work or pursuing a PhD. ROA. ROA Research Memoranda No. 008 https://doi.org/10.26481/umaror.2014008

Document status and date:

Published: 01/01/2014

DOI:

10.26481/umaror.2014008

Document Version:

Publisher's PDF, also known as Version of record

\section{Please check the document version of this publication:}

- A submitted manuscript is the version of the article upon submission and before peer-review. There can be important differences between the submitted version and the official published version of record.

People interested in the research are advised to contact the author for the final version of the publication, or visit the DOI to the publisher's website.

- The final author version and the galley proof are versions of the publication after peer review.

- The final published version features the final layout of the paper including the volume, issue and page numbers.

Link to publication

\footnotetext{
General rights rights.

- You may freely distribute the URL identifying the publication in the public portal. please follow below link for the End User Agreement:

www.umlib.nl/taverne-license

Take down policy

If you believe that this document breaches copyright please contact us at:

repository@maastrichtuniversity.nl

providing details and we will investigate your claim.
}

Copyright and moral rights for the publications made accessible in the public portal are retained by the authors and/or other copyright owners and it is a condition of accessing publications that users recognise and abide by the legal requirements associated with these

- Users may download and print one copy of any publication from the public portal for the purpose of private study or research.

- You may not further distribute the material or use it for any profit-making activity or commercial gain

If the publication is distributed under the terms of Article $25 \mathrm{fa}$ of the Dutch Copyright Act, indicated by the "Taverne" license above, 
Maastricht University

Research Centre for Education and the Labour Market | ROA

\section{Ability, academic climate, and going abroad for work or pursuing a PhD}

Daniëlle Bertrand-Cloodt

Frank Cörvers

Hans Heijke

\section{ROA Research Memorandum}

ROA-RM-2014/8

Research Centre for Education and the Labour Market Maastricht University

P.O. Box 616, 6200 MD Maastricht, The Netherlands

$\mathrm{T}+31433883647 \mathrm{~F}+31433884914$

secretary-roa-sbe@maastrichtuniversity.nl www.roa.nl 


\title{
Ability, academic climate, and going abroad for work or pursuing a PhD
}

\author{
Daniëlle Bertrand-Cloodt \\ Frank Cörvers \\ Hans Heijke
}

ROA-RM-2014/8*

June 2014

Research Centre for Education and the Labour Market

Maastricht University

P.O. Box 616, 6200 MD Maastricht, The Netherlands

$\mathrm{T}+31433883647 \mathrm{~F}+31433884914$

secretary-roa-sbe@maastrichtuniversity.nl

www.roa.nl

\footnotetext{
* The ROA Research Memorandum Series was created in order to make research results available for discussion, before those results are submitted for publication in journals.
} 


\section{Abstract}

\section{Ability, academic climate, and going abroad for work or pursuing a PhD**}

We investigate whether a creaming off of highly able students from Dutch universities is taking place. Therefore, we examine the relation between ability and the destination of recent graduates of Dutch universities. Students can choose to continue their academic career by investing in a PhD degree instead of working, taking into account that both options can be realized in the Netherlands as well as abroad. We also investigate whether these choices are affected by the climate in certain fields of study and universities. Using a data set of workers and PhD students who recently graduated from Dutch universities two probit equations are estimated simultaneously, one for the migration decision and one for the choice between working and pursuing a PhD. Our findings indicate that highly able graduates are significantly more likely than average graduates to go abroad. They invest more often in a PhD programme, which is positively correlated with their likelihood to go abroad. In addition, the climate promoting going abroad and starting PhD study is shown to have positive effects on the odds of going abroad and participating in a PhD programme. This particularly holds for the highly able.

JEL classification: F22, 123

Keywords: brain drain, migration, university graduate, PhD study, academic climate

Daniëlle Bertrand-Cloodt

Maastricht University

ROA

P.O. Box 616

NL-6200 MD Maastricht

The Netherlands

d.cloodt@alumni.maastrichtuniversity.nl
Frank Cörvers

Maastricht University

ROA and Department of Economics

P.O. Box 616

NL-6200 MD Maastricht

The Netherlands

frank.corvers@maastrichtuniversity.nl

Hans Heijke

Maastricht University

ROA and Department of Economics

P.O. Box 616

NL-6200 MD Maastricht

The Netherlands

h.heijke@maastrichtuniversity.nl

\footnotetext{
** Earlier versions of this paper were presented at the ROA Labour Workshop in September 2007 in Maastricht, the Transition in Youth 2007 Workshop in Ghent, the Migration Session at the 2007 EALE Conference in Oslo, the Spring 2008 Seminar Series of the Faculty of Spatial Sciences of the University of Groningen, the Second International Conference on Educational Economics in 2008 in Athens, and the 2012 CESifo Conference on International Migration in Munich. We would like to thank the participants of these sessions, as well as Lex Borghans, Marion Collewet, Andries de Grip, Christoph Meng, and Margarida Rodrigues for their helpful comments and discussions on earlier drafts of the paper. Thanks are also due to Erik Lintjens, who contributed to seminal versions of the paper.
} 


\section{Introduction}

Knowledge is becoming a main source of wealth for nations, businesses, and people (Machlup 1962; Lucas 1988; Castells 1996; Harris 2001; Rodrigues 2002). As a result, more and more resources are devoted to the production of knowledge. Within the process of knowledge generation, universities play a key role, being exclusive producers of knowledge and educators of the highly talented (Lindley 2002). The fundamental and applied research universities conduct gives them a competitive edge; they are the nursery of the most talented. By transferring their knowledge to students, universities prepare them for a professional career in which they apply their acquired knowledge to work or conduct research that generates new knowledge.

However, individuals who embody knowledge are scarce. If a domestic supply of knowledge does not satisfy demand, individuals embodying knowledge or knowledge-generating capacities may be transferred from other countries (Williams 2006). Park (2004) analyses the relevance of cross-border flows of young people for international knowledge transmission. The author finds evidence that international student flows across economies are a channel of R\&D spillover. According to Coe and Helpman (1995), such spillover is crucial for domestic productivity growth. Therefore, it is not surprising that highly talented university graduates are recruited in the race for a competitive edge in the production of knowledge.

This paper explores whether the Netherlands are indeed losing their highly able university graduates as they decide to migrate abroad. By analysing this brain drain, we examine the relation between graduates' abilities, indicated by their average master's degree grade, and their decision to go abroad. Highly able graduates are generally expected to be more susceptible to going abroad than average graduates. We also find the decision to go abroad to be correlated with the choice how to continue after graduation, that is, search for a regular job or enrol in a $\mathrm{PhD}$ programme. Highly able graduates are expected to be more susceptible to pursuing a $\mathrm{PhD}$, which can further raise their chances of going abroad. Therefore, simultaneously with the migration decision, we take the choice between working and pursuing a $\mathrm{PhD}$ into account. In summary, in this paper we determine whether a creaming off of highly able students from Dutch universities is taking place, since we expect more talented graduates to be more eligible for a $\mathrm{PhD}$ track and more susceptible to going abroad.

Gross and Schmitt (2006) show that, within a group of migrants to France, the low skilled are more driven by network effects (cultural clustering) than the high skilled. Going abroad is an investment in future opportunities that can raise returns during working life, whereas network effects can lower the costs of this investment (e.g. lower search costs). It is interesting to note that the academic environment of graduates can fulfil the same function as an international network that helps or stimulates them to go abroad as cultural or family connections for the low skilled. The international 
dimension of the academic climate of study programmes at universities could therefore be a driving factor behind the emigration of graduates.

The academic environment surrounding students can affect the decision to pursue a $\mathrm{PhD}$ too. The climate embodied by specific universities and studies towards pursuing a $\mathrm{PhD}$ (e.g. $\mathrm{PhD}$ position vacancies) can stimulate students to enrol as a $\mathrm{PhD}$ student. We test whether the climate promoting going abroad and the climate towards pursuing a $\mathrm{PhD}$ are strong stimuli in the investment decisions of graduates, particular among the highly able.

We develop a model of two simultaneous probit equations in which migration and additional training by starting a $\mathrm{PhD}$ programme are analysed, taking into account that graduates' choices are simultaneously made and affected by the academic climate embodied in their combinations of fields of study and universities. To examine these issues, we use data from a unique Dutch survey designed to collect detailed information on graduates' transition from school to work (WO-Monitor). Since the data exclusively concern graduates from Dutch universities interviewed approximately 18 months after graduation, the allocation and adjustment processes in their early labour market careers can be analysed.

The results outline to what extent graduates from Dutch universities are continuing their careers in the Netherlands or abroad by working or pursuing a $\mathrm{PhD} .{ }^{1}$ In line with expectations, we find that highly talented graduates more frequently opt for $\mathrm{PhD}$ study, which is positively correlated with their international mobility. However, being highly able increases the probability of moving abroad for work as well, although to a lesser extent than for a $\mathrm{PhD}$ degree. Consequently, highly able graduates are significantly more likely to go abroad than average graduates. Further, the climate embodied in certain fields of study and universities promoting going abroad and starting PhD study is shown to be a strong stimulus to invest in a migratory move and $\mathrm{PhD}$ study, respectively. In particular, these climates have strong effects on highly able graduates.

This paper is structured as follows. Section 2 introduces the theoretical framework of our analysis. Section 3 discusses the data set and Section 4 deals with our econometric approach, taking into account the simultaneity between the migration and $\mathrm{PhD}$ decisions. Section 5 presents the marginal effects of bivariate probit estimations and Section 6 checks the robustness of the model. Section 7 concludes the paper.

\section{Theoretical considerations}

In response to increased international policy attention on the importance of knowledge and knowledge-generating persons for economic growth, we examine the destination of the highly able

1. Throughout this paper we consider $\mathrm{PhD}$ students as participating in education, although the majority of $\mathrm{PhD}$ students in the Netherlands formally have an employee status. Moreover, when we refer to graduates, we mean recent graduates, that is, young workers who graduated approximately within the past 18 months. 
graduating from Dutch universities. In the development literature, brain drain is referred to as the flows of highly skilled migrants from developing to developed countries (Lien and Wang 2003). In addition, the Netherlands attract more highly skilled migrants from non-OECD countries than they lose to these countries (CPB 2007, based on OECD figures). As shown by CPB (2007), the Netherlands face a net loss of highly skilled people to other advanced countries that outweighs the inflow from developing countries. Although the term brain drain is often reserved to describe the flows of highly skilled people from developing to developed countries, it is not necessarily restricted to these flows. Davenport (2004, p. 618) defines brain drain as 'the departure at an appreciable rate of the most talented'. In our case brain drain refers to the emigration of recent university graduates from the Netherlands, particularly those with the highest final exam results and those investing in a $\mathrm{PhD}$ degree.

Since education is understood to be a key determinant of long-term growth (Lucas 1988), common wisdom suggests that brain drain is detrimental for the country of emigration (Beine et al. 2001). Indeed, a brain drain represents a negative externality on the population left in the source country (Bhagwati and Hamada 1974), since it reduces welfare (Miyagiwa 1991). ${ }^{2}$ It may even exist when students have a preference for returning home (at equal salaries) and employment opportunities exist at comparable average pay rates (Kwok and Leland 1982). The increasing number of Dutch students going abroad for their master's or bachelor's studies through the assistance of European programmes such as Erasmus and Socrates begs the question of whether more and more master's students are also going abroad after graduation. Oosterbeek and Webbink (2011) find that Dutch students who received a scholarship to study abroad end up living abroad afterwards more often than other students. In addition, the number of months spent studying abroad increases the probability of migration. The author correct for possible endogeneity bias in the variables for study abroad. Similar effects are found for the introduction of the Erasmus programme on German students (Parey and Waldinger 2010).

When students complete their master's studies they can opt to continue their studies by entering a $\mathrm{PhD}$ programme or by entering the labour market and searching for a suitable job. The opportunities for pursuing a $\mathrm{PhD}$ and for finding a proper job are not restricted to the country of graduation. Attractive possibilities for one's academic or professional career could be available at universities in foreign countries. Consequently, the decision to continue one's studies by starting a $\mathrm{PhD}$ programme or to enter the labour market is attached to the decision to stay in the country of graduation or to go abroad. The following briefly examines the theoretical considerations of these decisions. We hereby pay particular attention to the direction in which decisions taken by highly able graduates are expected to deviate from those of less able graduates.

2. Furthermore, the positive externalities of high-skilled immigrants for $R \& D$ and economic growth is mentioned by the CPB Netherlands Bureau for Economic Policy Analysis to advocate a selective immigration policy aimed at stimulating the inflow of high-skilled people in the Netherlands (CPB, 2007). 
Whether to continue university education by enrolling in a $\mathrm{PhD}$ programme represents a human capital decision, since $\mathrm{PhD}$ study involves incurring current costs for benefits expected sometime in the future (Mincer 1974; Becker 1975). The PhD track is attractive as long as the benefits over and above the benefits of a working life with only a master's degree outweigh the costs of investment in $\mathrm{PhD}$ study. Although highly able graduates may have higher forgone earnings from working in a regular job, they will face lower costs because they have to exert less effort to complete their $\mathrm{PhD}$ and may have a better chance of just successfully completing the $\mathrm{PhD}$ programme. Hence, highly able graduates are more likely to pursue a $\mathrm{PhD}$ than others.

In addition, the move abroad of a master's graduate represents an investment decision that involves benefits and costs (Sjaastad 1962; Mincer 1978; Greenwood 1985). Once again, highly able graduates are more likely to invest in going abroad, since they need to spend less on gathering the required information on opportunities to work or study abroad and have a higher probability of finding a betterpaying job abroad. The decision to migrate is somewhat different for graduates who opt for PhD study than for those who choose to work, because they are not ending their academic career but, instead, are looking for the best place to continue it. After all, graduates opting for a $\mathrm{PhD}$ track will weigh the costs and benefits of $\mathrm{PhD}$ study abroad against the costs and benefits of pursuing a $\mathrm{PhD}$ in the Netherlands. Highly able graduates may expect higher returns from going abroad, since they are more likely than other graduates to obtain a $\mathrm{PhD}$ position at a highly reputable university in another country, which in turn will deliver them a more prestigious and more marketable doctorate.

When analysing both investment decisions, we control for the study environment, which may stimulate graduates to continue their careers where their talents are most appreciated. This implies that graduates may be given a head start in terms of information or concrete alternatives. The climatic aspects this paper takes into account are the internationalization of studies and the scientific character of studies, which are further discussed below.

Exchange programmes were established by the European Commission in the late 1980s to stimulate the international mobility of university students in internships or as part of their study abroad (e.g. Erasmus/Socrates grant). ${ }^{3}$ In addition, many universities in the Netherlands have invested greatly in the internationalization of university education. Some master's programmes are even offered completely in English. This internationalization is expected to have a positive effect on the decision to go abroad after graduation. After all, individuals are thus better informed about working or studying abroad and may have improved their knowledge of foreign languages, whereas psychological thresholds limiting their ability to go abroad are reduced. Consequently, our analysis assumes that the international climate embodied by certain master's studies at universities stimulates graduates from these studies to go abroad.

3. See Borghans and Cörvers (2010) for trends of students leaving Western European countries to study abroad, including the Netherlands. 
In addition, obtaining a $\mathrm{PhD}$ position may be more common in some fields of study or universities than in others, since some focus more on education while others concentrate more on scholarly work. These differences have an impact on the extent to which students are prepared to participate in the $\mathrm{PhD}$ track. More importantly, these differences will also influence the number of available $\mathrm{PhD}$ positions for graduates at a university's particular department. Therefore, we assume the $\mathrm{PhD}$ climate to have a stimulating effect on graduates' probabilities of starting $\mathrm{PhD}$ study.

International orientation and participation in international scholar networks are essential for fundamental research. New scientific understandings, however, do not contribute to a scientific reputation unless they are internationally accepted. An international orientation and an international network of contacts are necessary ingredients for, on the one hand, finding research questions that push the boundaries of the exercise of scholarly work outwards and, on the other hand, acknowledging and in turn embracing the answers to these research questions. An international orientation and an international network of contacts in studies where PhDs are common will stimulate graduates who wish to continue their education by participating in $\mathrm{PhD}$ study to consider doing so abroad. We therefore expect some degree of correlation between the climate promoting going abroad and the climate promoting starting $\mathrm{PhD}$ studies. Therefore, both climate factors could play a role in the migration decision as well as in the $\mathrm{PhD}$ decision.

We focus on the transition of recent graduates from Dutch universities to a job or a $\mathrm{PhD}$ position in or outside the Netherlands. Due to limitations in our data set, we were unable to study in depth the return migration of graduates who acquired new skills abroad or the possible inflow of the highly talented from foreign countries to the Netherlands (e.g. Kuhn and McAusland 2006). We do, however, take into account that the decisions to enrol in $\mathrm{PhD}$ studies and to go abroad are simultaneous decisions. Furthermore, we pay attention primarily to the role of the ability of graduates in investment decisions. In particular, we want to determine whether highly able graduates are not only more susceptible to starting a $\mathrm{PhD}$ programme, but also more susceptible to going abroad than others, in line with our theoretical considerations, controlling for the two academic climate variables mentioned before. We thus aim to determine whether the Netherlands are indeed losing their highly talented university graduates.

\section{Data}

The data used were obtained from a survey among all recent graduates who were master's students at Dutch universities during the six college years 2001/2002 to 2006/2007. The surveys were carried out approximately 18 months after graduation, which implies that our sample contains the survey years 
2003 to $2008 .^{4}$ As a result, the survey examines university graduates at the beginning of their professional career. Our sample consists of 37,989 Dutch recent graduates, $4 \%$ of whom decided to migrate abroad and $10 \%$ of whom decided to participate in a $\mathrm{PhD}$ track. Note that we define migration as the movement of a recent Dutch graduate to another country.

The data set provides information about the talents of the graduates in the form of their average master's degree grade scores over all subjects taken. The grade scores can range from one (lowest) to 10 (highest), with six being the passing grade. We use an average master's degree grade of eight or higher as a measure of high ability, since in the Netherlands this group of graduates is potentially eligible for the so-called cum laude (with honours) degree. ${ }^{5}$

Since we analyse whether highly talented graduates are not only more susceptible to start $\mathrm{PhD}$ study but also more susceptible to go abroad than others, we conduct our analysis twice: once for all Dutch graduates in general (grade 6 and higher) and once for highly able Dutch graduates in particular (grade 8 and higher). We specifically focus on Dutch graduates instead of also including non-Dutch graduates. The reason for this is that non-Dutch graduates are more likely to migrate; so the inclusion of non-Dutch graduates leads to heterogeneity within our sample. Although the focus of our study is on Dutch graduates only, we include information about their having been born abroad, experience abroad, and having at least one parent who was born abroad.

Since we are modelling the decisions to go abroad and to pursue a $\mathrm{PhD}$, recent graduates can be distinguished along two lines. They can be either emigrants or non-emigrants and they can be $\mathrm{PhD}$ students or workers, that is, non-PhDs. Table 1 presents some personal characteristics of emigrants versus non-emigrants and of PhDs versus non-PhDs, respectively. Emigrants are more able (average master's degree grade 7.5) and participate more often in $\mathrm{PhD}$ studies (22\%) than graduates who stay in the Netherlands (10\%). In turn, $\mathrm{PhD}$ students are more able (average master's degree grade 7.7) and emigrate more often (8\%) than graduates who find a job (3\%). About one-fifth of the graduates are highly able, that is, have an average master's degree grade or average pre-university degree grade of eight or higher. ${ }^{6}$ Among emigrants and particularly PhD students, the percentages of highly able recent graduates are much higher than the average.

Besides being, on average, more able, emigrants and particularly $\mathrm{PhDs}$ are, on average, younger than non-emigrants and non-PhDs. Furthermore, women are less likely to go abroad and/or participate in $\mathrm{PhD}$ studies than men. Moreover, emigrants are more likely than non-emigrants to have been born abroad and to have experienced a period abroad during their studies. However, emigrants do not have parents who immigrated to the Netherlands more often than non-emigrants.

The factors that proxy for the climate or atmosphere during master's studies to migrate abroad or to pursue a $\mathrm{PhD}$ are explained in Appendix A. They are measured by accounting for the recent graduates

4. This survey was coordinated by the Research Centre for Education and the Labour Market (ROA) of Maastricht University.

5. We say potentially because supplementary conditions can vary between universities.

6. Pre-university degree grades are measured like master's degree grades. 
of all combinations of fields of study and universities ${ }^{7}$ (e.g. graduates in the natural sciences at Utrecht University). Table A.1 of Appendix A presents the percentages of recent graduates going abroad or pursuing a $\mathrm{PhD}$ for each study-university combination. As explained in Appendix A, the climate variables of all recent individual graduates are calculated by excluding their decisions from the aggregate climate variable of their study-university combinations. The average climate variables of all recent graduates are presented in the last few rows of Table 1. The average climate variable indicating the international environment of the study-university combinations is highest for recent graduates who emigrated from the Netherlands, followed by recent graduates who became PhD students. Similarly, the $\mathrm{PhD}$-conducive climate is highest for recent graduates who became $\mathrm{PhD}$ students and higher than average for those who emigrated.

Table 1 Characteristics of emigrants and non-emigrants and $\mathrm{PhD}$ and non-PhD students

\begin{tabular}{|l|c|c|c|c|c|}
\hline Characteristics & Emigrants & Non-emigrants & PhDs & Non-PhDs & Total \\
\hline & & & & & \\
\hline Ability characteristics & & & & & \\
\hline Average master's degree grade & 7.52 & 7.33 & 7.71 & 7.29 & 7.33 \\
\hline Master's degree grade $\geq 8$ (\%) & 31.3 & 19.7 & 44.1 & 17.5 & 20.0 \\
\hline Average pre-university degree grade & 7.45 & 7.28 & 7.56 & 7.26 & 7.29 \\
\hline Pre-university degree grade $\geq 8$ (\%) & 31.4 & 20.7 & 38.3 & 19.2 & 21.0 \\
\hline & & & & & \\
\hline Background characteristics & & & & & \\
\hline Age in years & 26.6 & 27.1 & 25.9 & 27.2 & 27.0 \\
\hline Female (\%) & 42.0 & 54.3 & 48.0 & 54.5 & 53.9 \\
\hline At least one parent is an immigrant (\%) & 2.2 & 2.2 & 1.5 & 2.3 & 2.2 \\
\hline Born abroad (\%) & 3.6 & 1.7 & 1.9 & 1.8 & 1.8 \\
\hline Experience abroad (\%) & 80.4 & 40.5 & 54.5 & 40.4 & 41.9 \\
\hline & & & & & \\
\hline Job characteristics & & & & & \\
\hline Going abroad (\%) & 100 & 0 & 8.0 & 3.2 & 3.7 \\
\hline Going abroad when highly able (\%) & 100 & 0 & 9.1 & 5.0 & 5.8 \\
\hline Pursuing a PhD (\%) & 21.6 & 9.5 & 100 & 0 & 9.8 \\
\hline Pursuing a PhD when highly able (\%) & 34.3 & 21.0 & 100 & 0 & 21.7 \\
\hline & & & & & \\
\hline Average climate & & & & & \\
\hline To go abroad (\%) & 8.0 & 5.0 & 6.4 & 5.0 & 5.1 \\
\hline To pursue a PhD (\%) & 12.0 & 10.0 & 18.0 & 9.0 & 9.9 \\
\hline & & & & & \\
\hline N & 1,353 & 36,636 & 3,773 & 34,216 & 37,989 \\
\hline
\end{tabular}

The climate variables can vary considerably between fields of study, as shown in Table 2 . We rank the fields of study from high to low, according to how conducive the climate is to pursuing a $\mathrm{PhD}$. The

7. Our sample consists of 13 universities. However, no information on whether graduates were born abroad is available for Leiden University. Therefore we did not include graduates of Leiden University in our sample and 12 universities remained for the analyses. Moreover, only study-university combinations with at least 25 graduates in the sample were taken into account. 
agricultural sciences have the climate most conducive to recent graduates going abroad. The climate promoting going abroad is weakest for the medical sciences, law, and particular educational sciences. The differences between universities with respect to an academic climate conducive to going abroad are particularly large for the social sciences, humanities, and economics. The natural sciences most stimulate an academic climate that promotes participation in $\mathrm{PhD}$ programmes, followed by engineering, the agricultural sciences, and the medical sciences. Note that the differences between universities with respect to their academic climates to pursue a $\mathrm{PhD}$ are very large for the natural sciences, social sciences, and engineering.

Table 2 Means, minima, and maxima of universities' climate variables by field of study

\begin{tabular}{|c|c|c|c|c|c|c|}
\hline \multirow{3}{*}{$\begin{array}{l}\text { Field of study } \\
\text { Natural sciences } \\
\end{array}$} & \multicolumn{3}{|c|}{$\begin{array}{c}\text { Climate } \\
\text { conducive to going abroad } \\
(\%) \\
\end{array}$} & \multicolumn{3}{|c|}{$\begin{array}{c}\text { Climate } \\
\text { conducive to pursuing a PhD } \\
(\%) \\
\end{array}$} \\
\hline & Mean & \multicolumn{2}{|c|}{$\begin{array}{c}\text { Range } \\
\text { Min. - Max. } \\
\text { at different } \\
\text { universities }\end{array}$} & Mean & \multicolumn{2}{|c|}{$\begin{array}{c}\text { Range } \\
\text { Min. - Max. } \\
\text { at different } \\
\text { universities }\end{array}$} \\
\hline & 4.66 & {$[1.84$} & $7.22]$ & 31.7 & {$[3.80$} & 45.73] \\
\hline Engineering & 6.30 & {$[1.59$} & $8.67]$ & 22.89 & {$[9.42$} & $37.65]$ \\
\hline Agricultural sciences $^{\mathrm{a}}$ & 15.74 & {$[15.74$} & $15.74]$ & 21.39 & {$[21.39$} & $21.39]$ \\
\hline Medical sciences & 2.36 & {$[0.71$} & $5.04]$ & 16.90 & {$[10.65$} & $21.21]$ \\
\hline Social sciences & 4.74 & {$[1.14$} & $27.15]$ & 7.76 & {$[3.53$} & $25.25]$ \\
\hline Humanities & 6.68 & {$[1.84$} & $26.64]$ & 6.17 & {$[2.66$} & $10.31]$ \\
\hline Economics & 6.41 & {$[1.80$} & 29.91] & 3.05 & {$[1.76$} & $6.33]$ \\
\hline Law & 2.41 & {$[0.47$} & $8.50]$ & 2.53 & {$[1.62$} & $4.04]$ \\
\hline Educational sciences & 0.84 & {$[0.00$} & $2.51]$ & 2.51 & {$[0.00$} & $6.02]$ \\
\hline
\end{tabular}

${ }^{a}$ There is no variation for the two climate variables because agricultural sciences can only be studied at Wageningen University.

To explore potential self-selection in the field of study and university choice, average pre-university degree grades are also taken into account. ${ }^{8}$ To determine whether the choice of field of study and university is correlated with the ability of the students, we calculate the correlations between climate factors and pre-university degree grades. The results are presented in Table 3. Table 3 clearly shows that pre-university degree grades are correlated with master's degree grades, with a correlation coefficient of 0.392 . This implies that the ability of university graduates can be predicted to some extent from their pre-university grades. In comparison, the correlations between pre-university grades and climate factors promoting either going abroad or pursuing a $\mathrm{PhD}$ are quite low. However significant, these low correlations seem to indicate only a very moderate self-selection of highly able students with respect to their choice for the international or scientific climate of particular fields of study or universities.

8. The average pre-university and master's degree grades are calculated by taking the average of the final grades over all subjects taken in secondary school and in the university, respectively. 
Finally, Table 3 includes variables that may be correlated with the climate promoting going abroad. Again, self-selection may occur if Dutch students with immigrant parents or Dutch students who were born abroad disproportionately often choose fields of study and universities that are more internationally oriented. Given their relatively low correlation coefficients of 0.144 and 0.015 , respectively, self-selection in this case is probably also very moderate. However, the correlation is somewhat higher between the average climate promoting going abroad and the experience abroad of recent graduates during their studies. In this case, the high correlation does not result from selfselection but from the international climate of study-university combinations stimulating students to go abroad during their studies.

\section{Table 3 Correlation matrix}

\begin{tabular}{|l|l|l|l|l|l|l|l|}
\hline Variable: & $\mathbf{1}$ & $\mathbf{2}$ & $\mathbf{3}$ & $\mathbf{4}$ & $\mathbf{5}$ & $\mathbf{6}$ & $\mathbf{7}$ \\
\hline 1 Average master's degree grade & 1.000 & & & & & & \\
\hline $\begin{array}{l}\text { 2 Average pre-university degree } \\
\text { grade }\end{array}$ & $0.392^{* * *}$ & 1.000 & & & & & \\
\hline $\begin{array}{l}\text { 3 Average climate promoting } \\
\text { going abroad }\end{array}$ & $0.082^{* * *}$ & $0.110^{* * *}$ & 1.000 & & & & \\
\hline $\begin{array}{l}\text { 4 Average climate promoting } \\
\text { pursuing a PhD }\end{array}$ & $0.121^{* * *}$ & $0.106^{* * *}$ & $0.212^{* * *}$ & 1.000 & & & \\
\hline $\begin{array}{l}\text { 5 At least one parent is an } \\
\text { immigrant }\end{array}$ & $0.024^{* * *}$ & $0.120^{* * *}$ & $0.144^{* * *}$ & $0.015^{* * *}$ & 1.000 & & \\
\hline 6 Born abroad & $0.011^{* *}$ & $0.016^{* * *}$ & $0.015^{* * *}$ & 0.002 & $-0.036^{* * *}$ & 1.000 & \\
\hline 7 Experience abroad & $0.134^{* * *}$ & $0.105^{* * *}$ & $0.232^{* * *}$ & $0.140^{* * *}$ & $0.064^{* * *}$ & $0.047^{* * *}$ & 1.000 \\
\hline
\end{tabular}

* Significant at the $10 \%$ level, ** significant at the $5 \%$ level, *** significant at the $1 \%$ level.

\section{Estimation strategy}

We assume that the decisions to go abroad and to invest in a $\mathrm{PhD}$ are simultaneously taken. $\mathrm{We}$ estimate these choices by bivariate probit analysis (e.g. Greene 2003). We do not assume either of these choices is made first. Both decisions may be affected by similar unobserved background characteristics. The binary choices between going abroad and staying in the Netherlands and between pursuing a $\mathrm{PhD}$ and working are each generated by a probit equation, whose errors are assumed to be correlated. Accordingly, the two probit equations are estimated simultaneously, which is efficient and gives the correlation between the two binary decisions.

Let $M_{i}$ be the dummy that denotes that graduate $i$ is moving abroad and let $P h D_{i}$ be the dummy that denotes that graduate $i$ is pursuing a $\mathrm{PhD}$. We consider the following system of interrelated equations:

$$
\begin{aligned}
& M_{i}^{*}=\gamma_{1} \mathbf{W}_{i}+\gamma_{2} \mathbf{C}_{i}+\varepsilon_{1 i} \\
& M_{i}=1 \text { if } M_{i}^{*}>0 \text { and } M_{i}=0 \text { otherwise }
\end{aligned}
$$




$$
P h D_{i}^{*}=\delta_{1} \mathbf{W}_{i}+\delta_{2} \mathbf{C}_{i}+\varepsilon_{2 i}
$$

$$
P h D_{i}=1 \text { if } P h D_{i}^{*}>0 \text { and } P h D_{i}=0 \text { otherwise }
$$

with

$$
E\left(\varepsilon_{1 i}\right)=E\left(\varepsilon_{2 i}\right)=0 ; \quad \operatorname{var}\left(\varepsilon_{1 i}\right)=\operatorname{var}\left(\varepsilon_{2 i}\right)=1 ; \quad \operatorname{cov}\left(\varepsilon_{1 i}, \varepsilon_{2 i}\right)=\rho \neq 0
$$

where $\mathbf{W}_{i}$ is an observed vector of exogenous controls, ${ }^{9} \gamma_{1}$ and $\gamma_{2}$ are vectors of parameters that determine the migratory movements, $\delta_{1}$ and $\delta_{2}$ are vectors of parameters that influence $\mathrm{PhD}$ participation, and $\mathbf{C}_{i}$ is a vector of institutional controls That capture both the climate promoting going abroad and the climate to pursue a $\mathrm{PhD}$ of a graduate's study-university combination (see the previous section).

The observed vectors of exogenous variables in equations (1) and (2) include personal characteristics that explain the investment behaviour of graduates after leaving university and comprise attributes such as ability (indicated by average master's degree grades), gender, age, foreign background, work and/or study experience acquired abroad during the study period, and cohort effects (i.e. year of survey). The attributes reflect individuals' human capital, which determines the expected costs and benefits of the investment decisions to go abroad and/or to start a $\mathrm{PhD}$ programme. We add the average pre-university degree grade as a control variable to an individual's attributes because the estimated effects of the climate factors could be biased by the influence of graduates' abilities on their choice of field of study and university (correlations are, however, low; see the previous section),

To estimate equations (1) and (2) efficiently - similar to estimating seemingly unrelated regression (SUR) models - we take the potential joint probability of $M$ and $P h D$ into account by allowing $\varepsilon_{1 i}$ and $\varepsilon_{2 i}$ to be correlated $(\rho)$, which is accomplished by using a bivariate joint distribution. The equations are estimated by full information maximum likelihood (FIML) by using the biprobit command of the econometric software package Stata 12 (StataCorp 2011).

\section{Estimation results}

The bivariate probit models of the choices between migrating and staying in the Netherlands and between pursuing a $\mathrm{PhD}$ and working are estimated twice: once for all graduates in general and once for highly able graduates, that is, those with an average master's degree grade of eight or higher. The

9. Note that $\mathbf{W}_{i}$ is defined similarly in both probit equations. The bivariate probit model in this paper is a SUR-type model, since the regressors are not restricted and do not include endogenous variables and the errors are correlated. The estimated coefficients in single-equation estimations (ordinary least squares) for SUR models with identical regressors in the set of equations have been shown to be efficient (Greene, 2003) and equal to the estimated coefficients in the SUR model. 
estimated marginal effects are presented in Table 4. Panel A of Table 4 shows the marginal effects on the migration decision for both the whole sample of graduates and highly able graduates. Panel B presents the marginal effects on the $\mathrm{PhD}$ decision for both groups of graduates.

Each marginal effect includes the direct effect of the estimated probit equation and the indirect effect of the other probit equation. The marginal effects in Table 4 represent the sum of the direct and indirect changes of the probability of migrating or continuing in a $\mathrm{PhD}$ track resulting from a unit change in the explanatory variable. The marginal effects on the migration and $\mathrm{PhD}$ decisions can be interpreted as (quasi-)elasticities evaluated at the means of the explanatory variables (Greene 1996; Christofides et al. 1997, 2000). The dummy variables are set to one instead of zero to calculate the marginal effects. The dummy variables are set to one if the grade is above eight (i.e. high ability), the individual is female, at least one parent is an immigrant, the individual was born abroad, the individual has work and/or study experience abroad, and if the year of the survey is later than 1996. The variables that proxy for the academic climate of a field of study at the university of graduation are measured in percentages, unlike the individual attributes, which are all dummy variables (except for age). We discuss our findings of the estimated probit equations in two steps: first, the results of the migration equation and, second, the results of the decision to pursue a $\mathrm{PhD}$. We are mainly interested in the effect of ability on migration and $\mathrm{PhD}$ participation, thereby controlling for the effect of a stimulating climate at the university to go abroad or enrol into a PhD track.

The estimation results of the migration choice show that ability, indicated by the average master's degree grade, has a significant and positive effect on migration: Highly able graduates who leave the university have a $1.38 \%$ higher probability of going abroad than recent graduates who scored below eight. The probability of emigrating increases further, by about $1 \%$, if recent graduates have an average pre-university grade of at least eight. This holds for both all graduates and highly able graduates. Females have a $1.5 \%$ lower probability of emigrating than males. This difference increases to $3 \%$ for highly able graduates. Having an international background, as measured by having been born abroad or having experience abroad, also increases the probability of emigration. These marginal effects are even stronger for highly able graduates.

Our findings on the climate variables indicate that graduating in an atmosphere in which more fellow students go abroad significantly increases the probability of emigration. An increase of a unit in the variable for a climate promoting going abroad (i.e. a change of one percentage point) increases the probability of going abroad by $0.12 \%$ for all graduates and $0.23 \%$ for highly able graduates. This may not seem to have very much impact, but differences in climates between study-university combinations can amount to 25 percentage points or more, as shown in Table 2. A climate promoting the pursuit of a $\mathrm{PhD}$ has hardly any impact on the decision to emigrate. 
Table 4 Marginal effects on migration and PhD decisions

\begin{tabular}{|c|c|c|c|c|}
\hline \multicolumn{5}{|l|}{ Panel A: Migration decision } \\
\hline \multirow[t]{2}{*}{ Explanatory variables $^{\mathrm{a}}$} & \multicolumn{2}{|c|}{ All graduates } & \multicolumn{2}{|c|}{ Highly able graduates } \\
\hline & (coef.) & (s.e.) & (coef.) & (s.e.) \\
\hline Average master's degree grade $\geq 8$ & $0.0138 * * *$ & 0.0029 & & \\
\hline Average pre-university grade $\geq 8$ & $0.0096 * * *$ & 0.0027 & $0.0123 * *$ & 0.0059 \\
\hline Female & $-0.0147 * * *$ & 0.0021 & $-0.0301 * * *$ & 0.0061 \\
\hline Age in years & -0.0005 & 0.0003 & -0.0013 & 0.0010 \\
\hline At least one parent an immigrant & 0.0005 & 0.0080 & -0.0158 & 0.0191 \\
\hline Born abroad & $0.0234 * *$ & 0.0093 & $0.0522 *$ & 0.0266 \\
\hline Experience abroad & $0.0565 * * *$ & 0.0029 & $0.0807 * * *$ & 0.0072 \\
\hline Climate & & & & \\
\hline To go abroad & $0.0012 * * *$ & 0.0001 & $0.0023 * * *$ & 0.0005 \\
\hline To pursue a $\mathrm{PhD}$ & $0.0002 *$ & 0.0001 & -0.0004 & 0.0003 \\
\hline
\end{tabular}

\begin{tabular}{|c|c|c|c|c|}
\hline \multicolumn{5}{|l|}{ Panel B: PhD decision } \\
\hline \multirow[t]{2}{*}{ Explanatory variables ${ }^{\mathrm{a}}$} & \multicolumn{2}{|c|}{ All graduates } & \multicolumn{2}{|c|}{ Highly able graduates } \\
\hline & (coef.) & (s.e.) & (coef.) & (s.e.) \\
\hline Average master's degree grade $\geq 8$ & $0.1078 * * *$ & 0.0058 & & \\
\hline Average pre-university grade $\geq 8$ & $0.0339 * * *$ & 0.0043 & $0.0676 * * *$ & 0.0118 \\
\hline Female & $-0.0175 * * *$ & 0.0032 & $-0.0635 * * *$ & 0.0118 \\
\hline Age in years & $-0.0099 * * *$ & 0.0007 & $-0.0208 * * *$ & 0.0024 \\
\hline At least one parent an immigrant & -0.0107 & 0.0105 & 0.0115 & 0.0481 \\
\hline Born abroad & 0.0054 & 0.0120 & 0.0211 & 0.0417 \\
\hline Experience abroad & $0.0216 * * *$ & 0.0035 & 0.0178 & 0.0131 \\
\hline \multicolumn{5}{|l|}{ Climate } \\
\hline To go abroad & -0.0004 & 0.0003 & 0.0012 & 0.0011 \\
\hline To pursue a $\mathrm{PhD}$ & $0.0065^{* * *}$ & 0.0002 & $0.0121 * * *$ & 0.0006 \\
\hline Correlation $(\rho)$ & $0.1627 * * *$ & & $0.1406^{* * *}$ & \\
\hline $\mathrm{N}$ & 37,989 & & 7,524 & \\
\hline Log-likelihood & $-11,434.271$ & & $-3,631.375$ & \\
\hline McFadden pseudo- $\mathrm{R}^{2}$ & 0.1570 & & 0.1182 & \\
\hline
\end{tabular}

${ }^{\mathrm{a}}$ Year dummies are not shown in the table.

* Significant at the $10 \%$ level, $* *$ significant at the $5 \%$ level, $* * *$ significant at the $1 \%$ level.

Our findings reveal a strong positive effect of almost $11 \%$ for the ability of graduates, as indicated by a high average master's degree grade, on estimated $\mathrm{PhD}$ choices. A high average pre-university grade further increases this probability by $3 \%$ for all graduates and by $7 \%$ for highly able graduates. For females and older graduates, the probability of enrolling in a $\mathrm{PhD}$ track is lower than for males and younger graduates. 
The climate variable for migration has no significant effect on the $\mathrm{PhD}$ choice, whereas the climate variable for the pursuit of a $\mathrm{PhD}$ has a significant positive effect on $\mathrm{PhD}$ choice. The latter effect is rather large, with a $0.65 \%$ change for a $1 \%$ increase in the climate variable. Highly able graduates are even more susceptible to a climate inspiring $\mathrm{PhD}$ studies. A $1 \%$ increase of the climate variable promoting enrolment in a $\mathrm{PhD}$ track increases the choice of a $\mathrm{PhD}$ track for highly able graduates by $1.21 \%$, which is nearly twice as much. The differences between study-university combinations with respect to $\mathrm{PhD}$ climate are even greater than for a climate promoting going abroad, as can be seen from Table 2.

Summarizing, we find that highly able graduates have a strong preference for pursuing $\mathrm{PhD}$ studies instead of working, which is correlated with their overrepresentation in the flow of graduates going abroad. Additionally, we find that factors that proxy for academic climate conducive to emigrating after graduation and to continuing in a $\mathrm{PhD}$ track play a significant role in the decisions to migrate and to pursue a $\mathrm{PhD}$, respectively. Of these factors, a climate conducive to pursuing a $\mathrm{PhD}$ has a particularly strong effect on the $\mathrm{PhD}$ decisions of highly able graduates.

\section{Further tests}

To test the robustness of our model, we considered other specifications as well. First, we focused on the simultaneous character of the estimated model. The results are presented in Appendix B, Table B.1. Two separate probit equations are estimated for the choice between going abroad and participating in $\mathrm{PhD}$ studies, neglecting the fact that both choices are simultaneously decided upon. A univariate probit model is generated to scrutinize the equations' simultaneity. Our results indicate that the estimates for the univariate model hardly differ from the estimates obtained when taking into account simultaneity.

Furthermore, we include dummy variables for the fields of study and universities instead of the climate variables for going abroad and pursuing a $\mathrm{PhD}$. The results are presented in Table B.2. We argue that the climate variables should be preferred to the dummy variables, since they have a clear meaning. The dummy variables can pick up very different characteristics of fields of study and universities without giving a clue about the reasons for the differences in impact. The results in Table B.2 are remarkably similar to those in the basic bivariate probit estimations. From the log-likelihood estimations, one can conclude that, in particular, the dummies for the fields of study matter. Including dummies for both fields of studies and universities increases the correlation coefficient $(\rho)$ as well as the estimated fit (measured by the log-likelihood) relative to the bivariate probit estimations with the two climate variables.

In Table B.3 we check the robustness of the results with respect to the pre-university grade. The preuniversity grade is taken into account as an additional explanatory variable to correct for possible endogeneity of the climate variables with respect to ability. Excluding the pre-university grade 
variable increases the estimated coefficient of the master's degree grade, because both are a measure of ability. More important are the results that the estimated coefficients of the climate variables hardly change when the pre-university grade is excluded from the regression. This provides further evidence, next to the low correlations between the climate variables and both ability variables found in Section 3 , that the climate variables are hardly influenced by self-selection with respect to ability. This result implies that the impact of ability on $\mathrm{PhD}$ and migration decisions probably does not suffer much from any endogeneity bias of the climate variables.

Finally, we note our focus on only Dutch graduates. An alternative model was constructed by including non-Dutch graduates (not presented in this paper). Our results indicate that the estimates for the alternative model hardly differ from those obtained for the model of only Dutch graduates.

\section{Conclusion}

This paper contributes to the discussion on brain drain within the advanced world. In response to increased international policy attention on the importance of knowledge and knowledge-generating persons for economic growth, we focus on the highly able who graduate from Dutch universities. We analyse to what extent they are creamed off by other countries by examining the relation between their ability, indicated by their average master's degree grade, and their destination after graduation. Besides the master's degree grade, the pre-university grade is taken into account. After graduation, graduates can choose to either continue their academic career by investing in $\mathrm{PhD}$ study or enter the labour market and search for a job, taking into account that both options can be realized in the Netherlands as well as abroad. We consider the role of possible unobserved factors in the simultaneous decisions to pursue a PhD and go abroad by assuming a correlation between the error terms in the bivariate probit model that generates these decisions. To estimate this model, we use a data set that considers the labour market position of graduates from Dutch universities 18 months after graduation, thus at the beginning of their professional career.

We find that the ability of graduates, as indicated by their master's degree grade, has a significant and positive effect on moving abroad. The pre-university grade has an additional impact on probabilities of going abroad or pursuing a $\mathrm{PhD}$. We also find that highly able graduates have a stronger preference for $\mathrm{PhD}$ study to working, which certainly contributes to an overrepresentation of the highly able in the flow of graduates going abroad. These findings indicate an outflow of the highly talented from the Netherlands to other countries. Unfortunately, we have no information available on their length of stay and possible return. We are therefore unable to study in depth the return migration (Kuhn and McAusland 2006) or possible inflow of the highly talented from other countries to the Netherlands. It is therefore premature to conclude that this brain drain from the Netherlands is permanent.

The academic climate of the field of study at the university of graduation plays an important role in both the migration and $\mathrm{PhD}$ decisions. Our findings indicate that graduation in an atmosphere where 
more fellow students go abroad significantly increases the odds of emigration but does not prompt graduates to participate in $\mathrm{PhD}$ studies. Furthermore, an inspiring climate to invest in $\mathrm{PhD}$ study generally triggers $\mathrm{PhD}$ participation but hardly influences the emigration choice. Although the climate variables may be endogenous, we find only low correlations between the climate variables and ability, as indicated by pre-university grades. By including the pre-university grade in the regression, we control as much as possible for self-selection with respect to ability in the climate variables.

From a policy perspective, we could argue that a small country such as the Netherlands could retain highly talented young academics by creating an academic environment with many graduates in $\mathrm{PhD}$ tracks. According to our results, improving the $\mathrm{PhD}$ climate is an effective way of encouraging (highly able) graduates to pursue a PhD in the Netherlands. Of course, some of the additional PhD students will choose to study outside the Netherlands, but an improved PhD climate can attract more highly talented graduates from other countries too, which could compensate for this leakage abroad.

\section{References}

Becker GS (1975) Human capital: a theoretical and empirical analysis, with special reference to education, 2nd edn. National Bureau of Economic Research, New York.

Beine M, Docquier F, Rapoport H (2001) Brain drain and economic growth: theory and evidence. J Dev Econ 64(1):275-289.

Bhagwati JN, Hamada K (1974) The brain drain, international integration of markets for professionals and unemployment. J Dev Econ 1(1):19-42.

Borghans L, Cörvers F (2010) The Americanization of European higher education and research. In Clotfelter CT (ed), American universities in a global market. National Bureau of Economic Research, University of Chicago Press, Chicago/London, pp 231-267.

Castells M (1996) The information age: economy, society and culture - The rise of the network society, I, reprinted 1999. Blackwell Publishers, Oxford.

Christofides LN, Stengos T, Swidinsky R (1997) On the calculation of marginal effects in the bivariate probit model. Econ Lett 54(3):203-208.

Christofides LN, Hardin JW, Stengos T (2000) Corrigendum to On the calculation of marginal effects in the bivariate probit model [Econ Lett 54, (1997) 203-208]. Econ Lett 68:339.

Coe DT, Helpman E (1995) International R\&D spillovers. Eur Econ Rev 39:859-887.

CPB (2007) Selectief arbeidsmigratiebeleid: Europees of nationaal? Het Beleidsplan Legale Migratie van de Europese Commissie onder de loep, CPB Memorandum, February 27, to the Interdepartementale Commissie Beleidsplan Legale Immigratie, CPB Netherlands Bureau for Economic Policy Analysis, The Hague.

Davenport S (2004) Panic and panacea: brain drain and science and technology human capital policy. Res Policy 33(4):617-630. 
Greene WH (1996) Marginal effects in the bivariate probit model, Working Paper EC-96-11, Department of Economics, Stern School of Business, New York University, New York.

Greene WH (2003) Econometric analysis, 5th edn. Pearson International Edition. Prentice Hall, New Jersey.

Greenwood MJ (1985) Human migration: theory, models, and empirical studies. J Regional Sci 25(4):521-544.

Gross M, Schmitt N (2006) Why do low- and high-skill workers migrate, flow evidence from France.

Working Paper No. 1797, CESifo, Munich.

Harris RG (2001) The knowledge-based economy: intellectual origins and new economic perspectives.

Int J Manag Rev 3(1):1-40.

Kuhn PJ, McAusland C (2006) The international migration of knowledge workers: when is brain drain beneficial? Working Paper 12761. National Bureau of Economic Research, Cambridge (MA).

Kwok V, Leland H (1982) An economic model of the brain drain. Am Econ Rev 72 (1):91-100.

Lien D, Wang Y (2003) Brain drain or brain gain: a revisit. J Pop Econ 18(1):153-163.

Lindley RM (2002) Knowledge-based economies: the European employment debate in a new context.

In: Rodrigues MJ (ed), The new knowledge economy in Europe: a strategy for international competitiveness and social cohesion. Edward Elgar, Cheltenham UK, pp 95-145.

Lucas RE (1988) On the mechanics of economic development. J Monetary Econ 22(1):3-42.

Machlup F (1962) The production and distribution of knowledge in the United States. Princeton

University Press, Princeton NJ.

Mincer J (1974) Schooling, experience, and earnings. National Bureau of Economic Research, New York.

Mincer J (1978) Family migration decisions. J Polit Econ 86(5):749-773.

Miyagiwa K (1991) Scale economies in education and the brain drain problem. Int Econ Rev 32(3):743-759.

Oosterbeek H, Webbink D (2011) Does studying abroad induce a brain drain? Economica78:347-366.

Parey M, Waldinger F (2010) Studying abroad and the effect on international mobility: evidence from the introduction of Erasmus. Econ J 121:194-222.

Park J (2004) International student flows and R\&D spillovers. Econ Lett 82:315-320.

Rodrigues MJ (ed.) (2002) The new knowledge economy in Europe: a strategy for international competitiveness and social cohesion. Edward Elgar, Cheltenham UK.

Sjaastad LA (1962) The costs and returns of human migration. J Polit Econ 70(5) Part 2: Investment in human beings:80-93.

StataCorp (2011) Stata Statistical Software: Release 12. StataCorp LP, College Station, TX.

Williams AM (2006) Lost in translation? International migration, learning and knowledge. Prog Hum Geog 30(5):588-607. 


\section{Appendix A The climate surrounding university education}

The variables that indicate the climate or atmosphere in a specific study-university combination promoting going abroad and pursuing $\mathrm{PhD}$ studies are calculated as fractions of probability. The climate variables are calculated for all graduates, including all non-Dutch graduates, because nonDutch graduates also influence the climate in specific study-university combinations promoting going abroad and pursuing $\mathrm{PhD}$ studies.

Moreover, the probabilities of emigration or pursuing a $\mathrm{PhD}$ are calculated by aggregating all individual graduates for each study-university combination. Since these probabilities are used to explain the choices made by the individual graduates, we exclude individual decisions from the aggregate climate effect of the field of study-university combination. We do so by applying the following idea.

The fraction of probability of choosing PhD study or going abroad (c) could simply be defined as follows:

$c=\frac{y}{n}$

where $y$ is the number of graduates choosing to pursue a $\mathrm{PhD}$ or going abroad and $n$ is the total number of graduates from the specific field of study-university combination, omitting subscripts that indicate the field of study-university combination and $\mathrm{PhD}$ and going abroad choices. The fractions $c$ of the various study-university combinations are calculated by using the data set of graduates of this paper (including non-Dutch graduates). The results are presented in Table A.1.

To exclude the individual decision of each graduate from the aggregate fraction of the studyuniversity combination, we define corrected fractions of probability of pursuing a $\mathrm{PhD}$ and going abroad, $c_{i}$, for each Dutch graduate in the sample:

For a graduate choosing to pursue a $\mathrm{PhD}$ or to go abroad, $c_{i}=\frac{y-1}{n-1}$

For a graduate not choosing to pursue a $\mathrm{PhD}$ or to go abroad, $c_{i}=\frac{y}{n-1}$

In the econometric analyses of this paper, the fractions $c_{i}$ are used instead of the $c$ fractions in Table A.1 below. In Equations (1) and (2) of Section 4, the corrected fractions of the two climate variables at the individual level are included in vector $\mathbf{C}_{i}$. Of course, for large samples of graduates from a given study-university combination, $c_{i}$ does not differ that much from $c$. 
Table A.1 Climate variables for universities and fields of study, with fraction $c$ in percentages

\begin{tabular}{|c|c|c|c|c|}
\hline University & Field of study & $\begin{array}{c}\text { Go abroad } \\
(\%)\end{array}$ & $\begin{array}{r}\begin{array}{r}\text { Pursue a PhD } \\
(\%)\end{array}\end{array}$ & $n$ \\
\hline \multirow[t]{5}{*}{ Leiden } & Social sciences & 2.2 & 6.6 & 995 \\
\hline & Medical sciences & 1.8 & 20.6 & 423 \\
\hline & Natural sciences & 5.4 & 44.6 & 354 \\
\hline & Law & 1.7 & 3.2 & 659 \\
\hline & Humanities & 6.1 & 8.0 & 693 \\
\hline \multirow[t]{7}{*}{ Groningen } & Economics & 2.4 & 2.4 & 1,169 \\
\hline & Social sciences & 1.6 & 9.0 & 1,127 \\
\hline & Medical sciences & 1.7 & 13.5 & 580 \\
\hline & Natural sciences & 6.9 & 39.0 & 474 \\
\hline & Law & 1.2 & 2.3 & 603 \\
\hline & Humanities & 8.1 & 6.4 & 854 \\
\hline & Engineering & 1.6 & 37.7 & 61 \\
\hline \multirow[t]{8}{*}{ Utrecht } & Economics & 5.0 & 6.3 & 181 \\
\hline & Social sciences & 1.6 & 3.5 & 1,926 \\
\hline & Medical sciences & 3.0 & 21.2 & 967 \\
\hline & Natural sciences & 4.7 & 27.7 & 1,149 \\
\hline & Educational sciences & 0.0 & 0.0 & 141 \\
\hline & Law & 1.6 & 1.9 & 663 \\
\hline & Humanities & 3.9 & 6.6 & 1,055 \\
\hline & Engineering & 8.7 & 26.2 & 38 \\
\hline \multirow[t]{5}{*}{ Rotterdam } & Economics & 3.3 & 2.5 & 1,902 \\
\hline & Social sciences & 1.1 & 4.4 & 354 \\
\hline & Medical sciences & 1.0 & 10.7 & 342 \\
\hline & Law & 0.5 & 1.6 & 401 \\
\hline & Humanities & 1.8 & 2.7 & 200 \\
\hline Delft & Engineering & 8.3 & 9.4 & 3,164 \\
\hline Eindhoven & Engineering & 6.6 & 18.3 & 2,109 \\
\hline \multirow[t]{2}{*}{ Twente } & Social sciences & 2.7 & 5.6 & 483 \\
\hline & Engineering & 4.8 & 16.6 & 1,493 \\
\hline Wageningen & Agricultural sciences & 15.7 & 21.4 & 2,113 \\
\hline \multirow[t]{6}{*}{ Maastricht } & Economics & 29.9 & 4.5 & 1,137 \\
\hline & Social sciences & 27.2 & 25.3 & 332 \\
\hline & Medical sciences & 5.0 & 15.5 & 1,422 \\
\hline & Natural sciences & 7.3 & 33.1 & 36 \\
\hline & Law & 8.5 & 2.2 & 566 \\
\hline & Humanities & 26.7 & 10.3 & 149 \\
\hline \multirow[t]{2}{*}{ UvA } & Economics & 2.4 & 1.8 & 475 \\
\hline & Social sciences & 2.0 & 5.7 & 1,586 \\
\hline
\end{tabular}




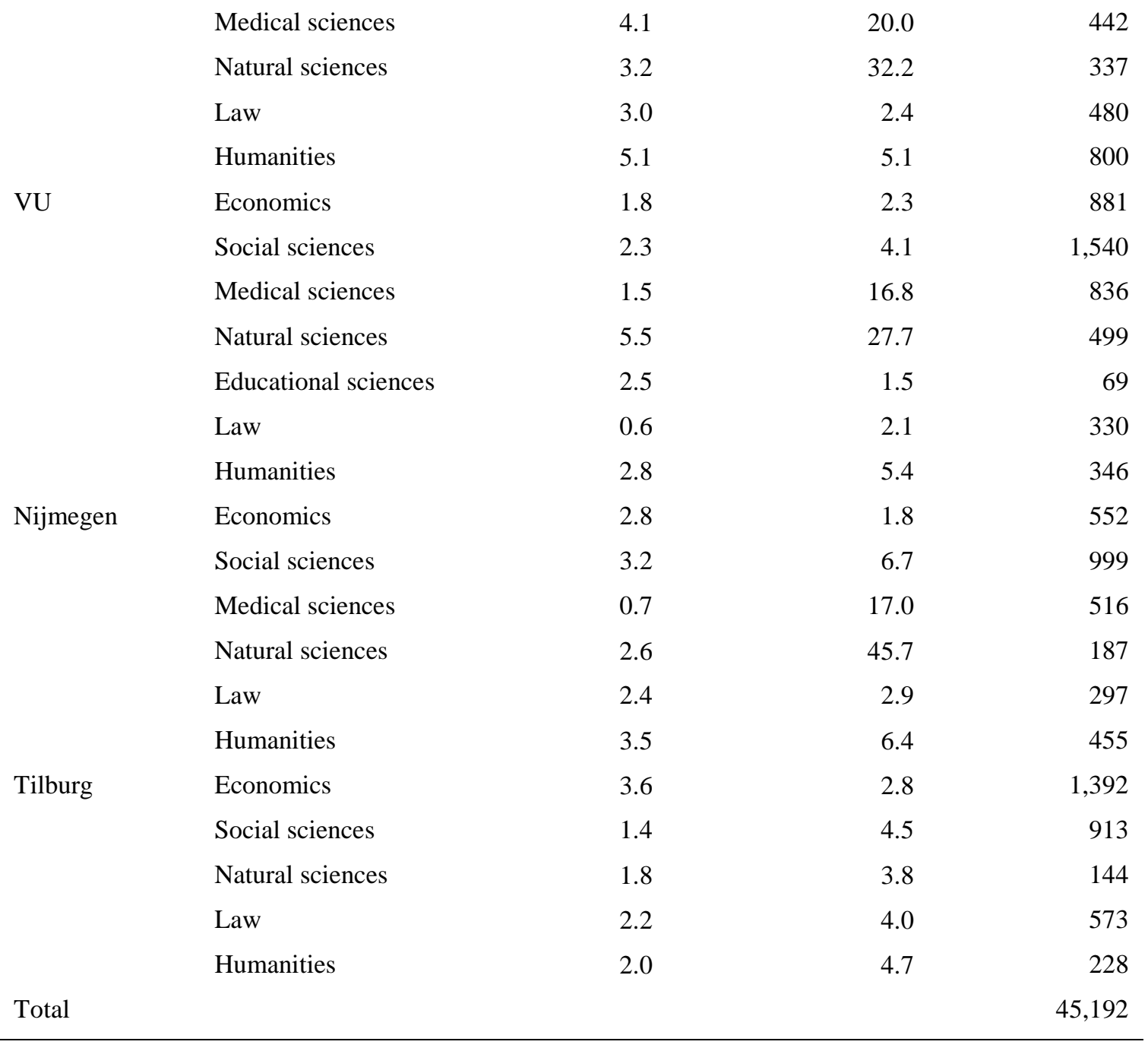




\section{Appendix B Robustness checks}

Table B.1 FIML coefficient estimates of the bivariate probit compared to univariate probits, all graduates

\begin{tabular}{|c|c|c|}
\hline Explanatory variables $^{\mathrm{a}}$ & Bivariate probit & Univariate probit \\
\hline \multicolumn{3}{|l|}{ Migration decision } \\
\hline Average master's degree grade $\geq 8$ & $0.0138 * * *$ & $0.0137 * * *$ \\
\hline Average pre-university grade $\geq 8$ & $0.0096^{* * * *}$ & $0.0096 * * *$ \\
\hline Female & $-0.0147 * * *$ & $-0.0146 * * *$ \\
\hline Age in years & -0.0005 & -0.0005 \\
\hline At least one parent is an immigrant & 0.0005 & 0.0087 \\
\hline Born abroad & $0.0234 * *$ & $0.0234 * *$ \\
\hline Experience abroad & $0.0565 * * *$ & $0.0565 * * *$ \\
\hline \multicolumn{3}{|l|}{ Climate } \\
\hline To go abroad & $0.0012 * * *$ & $0.0012 * * *$ \\
\hline To pursue a $\mathrm{PhD}$ & $0.0002 *$ & $0.0002 *$ \\
\hline $\mathrm{N}$ & & 37,989 \\
\hline Log-likelihood & & $-4,149.0681$ \\
\hline McFadden pseudo- $\mathrm{R}^{2}$ & & 0.1045 \\
\hline \multicolumn{3}{|l|}{ PhD decision } \\
\hline Average master's degree grade $\geq 8$ & $0.1078 * * *$ & $0.1078 * * *$ \\
\hline Average pre-university grade $\geq 8$ & $0.0339 * * *$ & $0.0339 * * *$ \\
\hline Female & $-0.0175 * * *$ & $-0.0174 * * *$ \\
\hline Age in years & $-0.0099 * * *$ & $-0.0098 * * *$ \\
\hline At least one parent is an immigrant & -0.0107 & -0.0108 \\
\hline Born abroad & 0.0054 & 0.0060 \\
\hline Experience abroad & $0.0216 * * *$ & $0.0216 * * *$ \\
\hline \multicolumn{3}{|l|}{ Climate } \\
\hline To go abroad & -0.0004 & -0.0004 \\
\hline To pursue a PhD & $0.0065 * * *$ & $0.0065 * * *$ \\
\hline Correlation $(\rho)$ & $0.1627 * * *$ & - \\
\hline $\mathrm{N}$ & 37,989 & 37,989 \\
\hline Log-likelihood & $-11,434.271$ & $-7,308.1056$ \\
\hline McFadden pseudo- $\mathrm{R}^{2}$ & 0.1570 & 0.1873 \\
\hline
\end{tabular}

${ }^{\mathrm{a}}$ Year dummies are not shown in the table.

* Significant at the $10 \%$ level, ** significant at the $5 \%$ level, *** significant at the $1 \%$ level. 
Table B.2 FIML coefficient estimates of the bivariate probit with different sets of dummy variables, all graduates

\begin{tabular}{|c|c|c|c|}
\hline Explanatory variables $^{\mathrm{a}}$ & $\begin{array}{l}\text { Bivariate probit } \\
\text { with field } \\
\text { dummies }\end{array}$ & $\begin{array}{l}\text { Bivariate probit } \\
\text { with university } \\
\text { dummies }\end{array}$ & $\begin{array}{l}\text { Bivariate probit } \\
\text { with field and } \\
\text { university dummies }\end{array}$ \\
\hline \multicolumn{4}{|l|}{ Migration decision } \\
\hline Average master's degree grade $\geq 8$ & $0.0098 * * *$ & $0.0116 * * *$ & $0.0098 * * *$ \\
\hline Average pre-university grade $\geq 8$ & $0.0078 * * *$ & $0.0087 * * *$ & $0.0080 * * *$ \\
\hline Female & $-0.0116^{* * *}$ & $-0.0129 * * *$ & $-0.0115^{* * *}$ \\
\hline Age in years & $-0.0006^{*}$ & $-0.0008 * *$ & $-0.0006^{*}$ \\
\hline At least one parent is an immigrant & 0.0106 & 0.0092 & 0.0091 \\
\hline Born abroad & $0.0249 * * *$ & $0.0220 * *$ & $0.0219 * *$ \\
\hline Experience abroad & $0.0571 * * *$ & $0.0556 * * *$ & $0.0544 * * *$ \\
\hline \multicolumn{4}{|l|}{ PhD decision } \\
\hline Average master's degree grade $\geq 8$ & $0.1010 * * *$ & $0.1185 * * *$ & $0.1026 * * *$ \\
\hline Average pre-university grade $\geq 8$ & $0.0382 * * *$ & $0.0477 * * *$ & $0.0377 * * *$ \\
\hline Female & $-0.0276 * * *$ & $-0.0326 * * *$ & $-0.0271 * * *$ \\
\hline Age in years & $-0.0107 * * *$ & $-0.0112 * * *$ & $-0.0102 * * *$ \\
\hline At least one parent is an immigrant & -0.0092 & -0.0096 & -0.0060 \\
\hline Born abroad & 0.0045 & 0.0027 & 0.0054 \\
\hline Experience abroad & $0.0223 * * *$ & $0.0291 * * *$ & $0.0216 * * *$ \\
\hline Correlation $(\rho)$ & $0.1684 * * *$ & $0.1572 * * *$ & $0.1766 * * *$ \\
\hline $\mathrm{N}$ & 37,989 & 37,989 & 37,989 \\
\hline Log-likelihood & $-11,440.385$ & $-12,084.636$ & $-11,354.528$ \\
\hline McFadden pseudo- $\mathrm{R}^{2}$ & 0.1565 & 0.1090 & 0.1628 \\
\hline
\end{tabular}

${ }^{a}$ Year dummies, field dummies, and university dummies are not shown in the table.

* Significant at the $10 \%$ level, ** significant at the 5\% level, *** significant at the $1 \%$ level. 
Table B.3 FIML coefficient estimates of the bivariate probit with and without pre-university grades, all graduates

\begin{tabular}{|c|c|c|}
\hline Explanatory variables $^{\mathrm{a}}$ & $\begin{array}{c}\text { With pre-university } \\
\text { grades }\end{array}$ & $\begin{array}{c}\text { Without pre-university } \\
\text { grades }\end{array}$ \\
\hline \multicolumn{3}{|l|}{ Migration decision } \\
\hline Average master's degree grade $\geq 8$ & $0.0138 * * *$ & $0.0176 * * *$ \\
\hline Average pre-university grade $\geq 8$ & $0.0096 * * *$ & - \\
\hline Female & $-0.0147 * * *$ & $-0.0152 * * *$ \\
\hline Age in years & -0.0005 & -0.0005 \\
\hline At least one parent is an immigrant & 0.0005 & 0.0008 \\
\hline Born abroad & $0.0234 * *$ & $0.0237 * *$ \\
\hline Experience abroad & $0.0565 * * *$ & $0.0568 * * *$ \\
\hline \multicolumn{3}{|l|}{ Climate } \\
\hline To go abroad & $0.0012 * * *$ & $0.0012 * * *$ \\
\hline To pursue a $\mathrm{PhD}$ & $0.0002 *$ & $0.0002 * *$ \\
\hline \multicolumn{3}{|l|}{ PhD decision } \\
\hline Average master's degree grade $\geq 8$ & $0.1078 * * *$ & $0.1250 * * *$ \\
\hline Average pre-university grade $\geq 8$ & $0.0339 * * *$ & - \\
\hline Female & $-0.0175 * * *$ & $-0.0196 * * *$ \\
\hline Age in years & $-0.0099 * * *$ & $-0.0104 * * *$ \\
\hline At least one parent is an immigrant & -0.0107 & -0.0127 \\
\hline Born abroad & 0.0054 & 0.0060 \\
\hline Experience abroad & $0.0216^{* * *}$ & $0.0224 * * *$ \\
\hline \multicolumn{3}{|l|}{ Climate } \\
\hline To go abroad & -0.0004 & -0.0005 \\
\hline To pursue a PhD & $0.0065 * * *$ & $0.0066 * * *$ \\
\hline Correlation $(\rho)$ & $0.1627 * * *$ & $0.1632 * * *$ \\
\hline $\mathrm{N}$ & 37,989 & 37,989 \\
\hline Log-likelihood & $-11,434.271$ & $-11,538.819$ \\
\hline McFadden pseudo- $\mathrm{R}^{2}$ & 0.1570 & 0.1542 \\
\hline
\end{tabular}

${ }^{\mathrm{a}}$ Year dummies are not shown in the table.

* Significant at the $10 \%$ level, ** significant at the $5 \%$ level, *** significant at the $1 \%$ level. 